\title{
WAWACAN RADEN PANII ATMAKA: SUATU KAJIAN PERSPEKTIF HISTORIS
}

\author{
Oleh Erlan Saefuddin \\ Politeknik Negeri Media Kreatif Depok \\ Email:naufalislam@yahoo.com \\ Naskah diterima: 8 Januari 2010 \\ Naskah disetujui: 12 Februari 2010
}

\begin{abstract}
Abstrak
Wawacan Raden Panji Atmaka (WRPA) merupakan suatu karya sastra yang diindikasikan mengandung unsur-unsur sejarah. Oleh sebab itu, pengkajiannya menggunakan pendekatan sejarah. Untuk mendukung pendekatan ini, diterapkan metode komparatif-analitis supaya dapat dibuktikan bahwa indikasi-indikasi di dalam teks yang menunjukkan hubungan dengan sejarah. Untuk pemahamannya yang lebih luas, terutama dalam memperkirakan konteks zaman dan akar historis dari karya ini, perlu kiranya dibahas jejak-jejak historis yang relevan secara umum. Selanjutnya dianalisis unsur-unsur historis di dalam wawacan ini untuk memahami maknanya yang merefleksikan realitas zaman tertentu. Pada akhirnya, dapat ditemukan bahwa WRPA adalah sebuah karya yang memiliki unsur-unsur legendaris dari sejarah Kasunanan Surakarta dan Kesultanan Yogyakarta. Unsur-unsur legendaris itu meliputi dua aspek penting dalam masalah sejarah, yaitu latar tempat dan nama tokoh. Latar tempatnya adalah Yogya, Solo, Surakarta, Magelang, dan Kedu. Nama tokohnya adalah Sinuhun/Sultan Mataram dan Pangeran Mangkunagara. Latar tempat dan nama tokoh WRPA itu bersifat legendaris karena historis faktualnya hanya dari segi penamaan. Secara umum, WRPA juga menunjukkan satu bukti mengenai sejarah transformasi kebudayaan Sunda dengan kebudayaan Jawa.
\end{abstract}

Kata kunci: Wawacan Raden Panji Atmaka, aspek historis, sejarah.

\section{Abstract}

Wawacan Raden Panji Atmaka (WRPA) is one works of literature indicated to have history elements. Therefore, the research use history approach. For support this approach, Analysis-comparative method is used for can be proved that indications in that text shows relation with history. For understanding in wider range, especially in conjecture period context and history root from this works, it is necessary to discuss the relevant history trail in a general. End then the history elements is to analyze the meaning of in this wawacan which reflects of certain period. In the end can be founded that WRPA is one work have legendary elements from history of Kasunanan Surakarta and Kesultanan Yogyakarta. The legendary elements consist of two important aspects in the historical problems, those are the places and the figures. The places are Yogya, Solo, Surakarta, Magelang, and Kedu. The figures are Sinuhun/Sultan Mataram and Pangeran Mangkunagara. Those becomes a legend because the factual history only in naming. Generally WRPA also shows one prove about transformation history of Sundanese culture and Java culture.

Keywords: Wawacan Raden Panji Atmaka, historical aspect, history. 


\section{A. PENDAhuluan}

Dalam kerangka kemimesisan, sebuah karya sastra tidak dapat dilepaskan kaitannya dengan kenyataan. Sering kali karya sastra itu merefleksikan realitas dari pengalaman manusia. Terkadang karya tersebut merupakan potret yang menggambarkan kenyataan yang pernah terjadi. Dalam hal ini pengkajian suatu karya sastra tidak jarang dihubungkan dengan perspektif historis. Dan ternyata pada umumnya dengan pengaitan ini, kita dapat menemukan makna karya sastra yang lebih kaya dan lebih tepat konteksnya.

Namun demikian, hubungan kemimesisan tersebut, khususnya secara historis tidaklah linier. Karya tidak secara murni dan lugas menyatakan realitas yang direkamnya. Kerumitan muncul karena kenyataan yang masuk ke dalamnya bersimbiosis dengan dunia imajiner pengarangnya. Dalam hasil ciptanya, realitas berasimilasi dengan imajinasi sebagai satu kesatuan yang membangun keutuhan.

Masalah tersebut semakin rumit ketika dikaitkan dengan ilmu sejarah dan sastra tradisional, khususnya di Nusantara. Karya-karya sastra lama diciptakan oleh alam pikiran pengarang dan karakteristik pandangan masyarakatnya yang didominasi oleh magis-mistisisme. Peradaban masa lalu memang mengutamakan sistem kepercayaan daripada rasionalisme.

Sementara itu, di sisi lain, ilmu sejarah menuntut adanya kemurnian realitas. Kepedulian utamanya adalah fakta-fakta sejarah, kejadian-kejadian nyata di masa lalu yang dapat dibuktikan secara metodologis. Oleh sebab itu, karya sastra yang mengandung unsur-unsur historis sering membuat kecewa para sejarawan karena menyatupadunya antara realitas dengan imajinasi. Simpulan para sejarawan tidak jarang menjadi negatif karena sedikitnya aspek sejarah dan dominannya unsur-unsur irasional yang sangat sulit diterima sebagai kenyataan.

Oleh sebab itu, menurut Djamaris (2007: 9-10) masalah itu perlu didudukkan dalam konteks sastra sejarah. Ia tidak dapat dilihat hanya dari pendekatan sejarah karena nantinya dapat membingungkan dan menyesatkan. Namun, pendekatan sastra semata tidak akan membuahkan hasil yang maksimal karena pemaknaannya yang dangkal, konteks zamannya yang sulit ditelusuri, dan kebermanfaatannya yang kurang tergali. Untuk karya-karya seperti ini, pendekatan integral sastra dan sejarah diyakini dapat menghasilkan kajian yang tepat, proporsional, dan komprehensif.

Dengan demikian, masalah pembicaraan sastra dan sejarah selalu berada dalam ketegangan yang menarik untuk kita perhatikan. Penyatuan dan pemilahan keduanya mengandung tantangan tersendiri sehingga pendudukan secara tepat dan pemaknaan secara menyeluruh terhadap suatu karya sastra dapat diwujudkan.

Masalah seperti tersebut kiranya muncul di dalam sebuah karya sastra Sunda lama yang berjudul Wawacan Raden Panji Atmaka (disingkat WRPA). Hal ini disebabkan oleh perkiraan bahwa di dalam balutan imajinasi yang dominan WRPA mengandung unsur-unsur yang berbau sejarah. Karena itu, teks ini menarik dikaji dari perspektif historisnya.

WRPA dapat dikatakan sebagai cerita Panji dari khazanah sastra Sunda. Timbul pertanyaan yang menarik: mengapa karya sastra dari khazanah 
kesastraan Jawa bisa hadir di Tatar Sunda. Untuk menjawab pertanyaan ini, dikemukakan perspektif historis secara umum yang relevan dengan WRPA, terutama yang berkaitan hubungan antara Sunda dengan Jawa sehingga didapatkan pemahaman yang lebih luas, terutama dalam menentukan perkiraan konteks zaman dan akar historis dari karya ini. Selain itu, dibicarakan masalah yang menyangkut unsur-unsur yang ada kaitannya dengan sejarah dalam WRPA supaya memahami makna WRPA yang merefleksikan realitas zaman tertentu.

Secara metodologis, WRPA dilihat berdasarkan perpektif historis. Dalam hal ini, digunakan analisis untuk menjawab enam pertanyaan $(5 \mathrm{~W}$ dan 1 $\mathrm{H})$ yang merupakan elemen dasar penulisan sejarah, yaitu what (apa), when (kapan), where (dimana), who (siapa), why (mengapa), dan how (bagaimana). Pertanyaan-pertanyaan itu konkretnya adalah: Apa (peristiwa apa) yang terjadi? Kapan terjadinya? Di mana terjadinya? Siapa yang terlibat dalam peristiwa itu? Mengapa peristiwa itu terjadi? Bagaimana proses terjadinya peristiwa itu? (Hardjasaputra, 1999; Hardjasaputra, 2004). Analisis itu berada dalam ranah kemungkinan yang dapat ditemukan di dalam WRPA. Artinya, jawaban itu akan sebanyak-banyak ditelusuri meskipun kiranya semua pertanyaan tidak dapat terjawab. Jawabannya tidak bersifat lugas karena terkait dari hakikat WRPA sebagai sebuah karya sastra yang didominasi unsur imajinatif.

\section{B. HASIL DAN BAHASAN}

\section{Perspektif Historis yang Relevan secara Umum}

Dalam penelusuran aspek historis secara umum, kiranya tepat kita bahas masalah hubungan dua kebudayaan yang bertetangga: Sunda dan Jawa. Karena asumsi dasarnya WRPA dipengaruhi kesusastraan Panji dari Jawa, pembicaraan difokuskan pada pengaruh Jawa terhadap Sunda, khususnya di bidang kesastraan.

$$
\text { Ricklefs (2005: }
$$

menyebutkan bahwa pengaruh Jawa dapat ditemukan dalam tradisi-tradisi kesastraan Sunda. Menurut Graaf (2003: 123), ternyata pengaruh ini diawali oleh hubungan yang telah berlangsung sejak masa pra-Islam. Artinya, peradaban Jawa sudah memberikan pengaruh sebelum Islam masuk ke Tatar Sunda dan begitu pula sebaliknya.

Dari kisah yang sampai kepada kita, hubungan awal terjadi antara Jawa Barat dengan Jawa Timur. Paling tidak terdapat dua legenda yang mengisahkan hubungan antara Jawa Barat dan Jawa Timur. Satu cerita termuat pada Serat Kandha dan babad dalam beberapa versi, baik di Jawa Tengah maupun di Jawa Timur. Cerita ini mengisahkan bahwa Kota Kerajaan Majapahit itu didirikan oleh usaha seorang pangeran Sunda yang konon terpaksa melarikan diri dari tanah kelahirannya. Hubungan orang Sunda dengan Jawa terlihat pada kisah lainnya dalam balada Jawa atau balada JawaBali yang diperkirakan berasal dari abad XV atau XVI. Kisah ini menggambarkan suatu ekspedisi Raja Sunda ke Majapahit dan kekalahannya dalam pertempuran melawan Raja 
Jawa. Legenda ini pun menyebutkan peranan penting seorang Putri Sunda yang seharusnya diperuntukkan bagi Raja Majapahit. Fakta historis bisa disimpulkan bahwa adanya legendalegenda tersebut menandakan hubungan Jawa dan Sunda yang tidak selalu bersahabat di masa lampau. Namun kemudian, semenjak penduduk Islam dari Jawa Tengah menguasai kota-kota pelabuhan di Jawa Barat, hubungan Jawa Barat dengan Jawa Timur tidak berlanjut (Graaf, 2003: 123-124).

Keruntuhan Kerajaan Sunda pada tahun 1579 memecah belah wilayah kekuasaannya menjadi beberapa pusat pemerintahan (Lubis, 2000: 23). Pusat-pusat administrasi dan kebudayaan beralih ke kabupaten. Ketiadaan pusat kebudayaan dan agama yang adikuasa di wilayah Sunda tidak memandekkan gerak budaya masyarakatnya. Rakyat tetap mengembangkan dan menyebarkan pengetahuan dan tradisi yang tidak didapati pada komunitas budaya lain di Nusantara. Contohnya adalah tradisi lisan yang kaya, seperti reportoar pantun sebentuk sajak bersuku kata delapan per larik yang dari dulu, bahkan sampai saat ini masih hidup dan tradisi tulis pada lontar yang sudah lama berkembang (Moriyama, 2005: 2).

Mataram memanfaatkan keadaan tersebut untuk mengklaim menguasai Tanah Sunda kemudian mengangkat para bupati dengan gelar mantri agung. Akan tetapi realitasnya, para bupati ini masih memegang otoritas penuh terhadap rakyatnya (Hardjasaputra, 2004: 20-24; Lubis, 2000: 23-24). Gambaran untuk masalah ini dapat tertihat dari sebuah karya sastra Sunda lama yang berjudul Mantri Jero (Sastrahadiprawira, 1980). Ekspansi Mataram membawa banyak pengaruh. Kebudayaan Jawa tidak hanya mewarnai kesenian, tetapi juga administrasi pemerintahan, gaya hidup, dan bahasa. Selama hampir dua ratus tahun sastra Sunda berkembang menurut estetika Jawa. (Moriyama, 2005: 2)

Pengaruh Mataram yang sampai kini masih terlihat adalah pada bidang bahasa. Bahasa Sunda yang mulanya egaliter berubah menjadi mengenal dan memiliki undak-usuk bahasa (tingkatan-tingkatan bahasa). Keegaliteran bahasa Sunda terlihat dalam beberapa naskah yang berasal dari zaman Kerajaan Sunda pada abad XVI Masehi, yaitu Sanghyang Siksa Kanda (ng) Karesian (1518) dan Carita Parahyangan (sekitar 1580). Perubahan ini disebabkan oleh determinasi Mataram yang menerapkan aturan bahwa bahasa dalam administrasi pemerintahan diharuskan memakai bahasa Jawa yang memiliki tingkatan-tingkatan bahasa. Bahasa Jawa mengenal bahasa halus, sedang, dan kasar. Lebih jauh lagi, bahasa ini wajib dikuasai, bahkan salah satu parameter kebangsawanan seorang menak (kelompok bangsawan dan elite politik di kalangan masyarakat Sunda) adalah penguasaan bahasa Jawa. Pengaruh ini dapat ditemukan dalam surat-menyurat pribadi, karya sastra, dan karya sastra sejarah yang ditulis kaum menak Sunda, seperti dalam bentuk babad, wawacan, dan sajarah (Lubis, 2003: 329).

Pada abad ke-19, kehidupan kesenian di Tatar Sunda menunjukkan adanya pengaruh dari tradisi di luar Sunda. Kesenian istana (yang sering 
disebut sebagai bagian dari tradisi besar) adalah kesenian Sunda yang dapat dilacak melalui sumber, baik berupa naskah yang tergolong historiografi tradisional maupun peninggalan berupa benda. Jenis kesenian ini dianggap sebagai kesenian bermutu tinggi dan indah yang berorientasi pada konsep nilai "halus" dan "kasar".

Satu di antara seni istana ini adalah seni sastra. Sampai pertengahan abad ke-19, karya sastra dan karya sastra-sejarah, ditulis dalam bahasa Jawa dengan aksara Sunda-Jawa. Setelah pertengahan abad ke-19, banyak karya sastra dan karya sastra sejarah ditulis dalam bahasa Sunda atau dalam bahasa Melayu dengan menggunakan huruf Pegon (tulisan Arab untuk bahasa Sunda dan Jawa) atau Latin. Karena budaya tulis pada waktu itu dikuasai kaum bangsawan dan para ulama, seni sastra ini lebih banyak dihasilkan kaum menak. Beberapa judul karya sastra sejarah yang ditulis pada abad ke-19 adalah Sejarah Sukapura, Kitab Pancakaki, Sejarah Galuh, Sejarah Bopati, Babad Sumedang, Babad Nusa Jawa, Piwulang Batara Sunu, dll. (Lubisdkk.,2003:444).

Pada akhir abad ke-19 sampai awal abad ke-20, bentuk karya sastra wawacan dianggap sebagai puncak cita-cita kesusastraan Sunda sehingga seseorang itu baru dianggap sebagai sastrawan terkemuka bila sudah menghasilkan beberapa wawacan. Kaum menak mulai dari wedana sampai bupati ada yang tergolong sastrawan yang di antaranya menulis Wawacan Sajarah Galuh, Wawacan Batara Rama, Wawacan Angling Darma, Wawacan Aji Saka, dll. (Lubis dkk., 2003: 446).

Seni suara yang merupakan pengaruh budaya Jawa adalah seni tembang, yaitu nyanyian berbentuk pupuh yang sangat digemari kaum bangsawan. Ada tujuh belas jenis pupuh, antara lain asmarandana, kinanti, sinom, magatru, mijil, pangkur, dan dangdanggula. Perbedaannya dengan kawih, bahasa tembang bisa halus, sedang, atau kasar, tetapi bahasa kawih umumnya kasar. Tembang dalam bahasa halus disebut mamaos. Jenis tembang terkenal adalah tembang cianjuran yang ditembangkan oleh Dalem Pancaniti (Lubis dkk., 2003: 447). Seni yang juga disebut danding tersebut dipandang sebagai pengaruh estetika Jawa yang paling jernih karena danding diadaptasi dari tembang macapat (Moriyama, 2005: 2-3).

Raden Haji Muhamad Musa, Hoofd Penghulu Limbangan, dengan bantuan K.F. Holle, penasihat pemerintah untuk urusan Bumi Putera, berjasa menghidupkan kembali bahasa dan sastra Sunda. Ia cukup produktif berkarya. Karya-karyanya di antaranya adalah Carita Abdurahman jeung Abdurahim, Wawacan Panji Wulung, dan Dongeng-Dongeng Pieunteungeun (Ekadjati, 1994: 18, 47-68). Ia termasuk pengarang yang memiliki "semangat baru". Musa adalah satu tokoh yang mencoba merumuskan cara baru dalam memaknai dunia sekitarnya. Tradisi dan modernitas mampu ia padukan. Ia menata kembali tradisi budaya Sunda dengan memadukan unsur-unsur budaya cetak Barat, rasionalitas, dan kekuasaan kolonial dengan pengetahuan masyarakat. Karya-karyanya yang tidak kurang dari 14 judul buku dipandang berperan penting dalam kehidupan kesusastraan Sunda juga diakui oleh kalangan terpelajar Sunda serta pegawai-pegawai kolonial Belanda. Buku-bukunya 
dipakai di sekolah-sekolah pemerintah bersubsidi dan dibaca oleh khalayak luas. (Moriyama, 2005: 7)

Tokoh lain yang perlu disebutkan karena jasanya adalah Bupati R.A.A. Martanagara. Jasanya besar karena produktivitasnya dalam berkarya dan memberi bukti adanya hubungan kesundaan dan kejawaan karena banyak karyanya yang berupa saduran dari karya sastra Jawa. Selain sebagai birokrat, bupati yang satu ini juga dikenal sebagai sastrawan yang turut memberikan sumbangan berharga bagi dunia kesusastraan Sunda. Ia produktif menulis sekitar tahun 1920-an setelah pensiun tahun 1918. Hal ini dapat dimaklumi mengingat ketika ia masih menjabat bupati, kesibukan pemerintahan telah menyita banyak waktunya. Bupati asal Sumendang ini mampu menulis karena memiliki bekal pengetahuan bahasa Jawa yang diperolehnya di rumah Raden Saleh (ia terpaksa belajar bahasa Jawa karena semua pegawai di rumah Raden Saleh "harus" berkomunikasi dalam bahasa tersebut) sewaktu bersekolah di Semarang juga berkat bakat seni yang mengalir di dalam darahnya. Ia mengerjakan Wawacan Batara Rama berdasarkan Epos Ramayana yang termasyur itu melalui Serat Rama yang ditulis dalam bahasa Jawa. Tulisan Beliau yang dapat digolongkan ke dalam historiografi tradisional (karya sastra yang mengandung unsur sejarah), di antaranya sebagai berikut: Satu karya yang ditulis dalam bentuk puisi, berhuruf pegon, serta berbahasa Sunda, yaitu Babad Sumedang (1921). Karya lainnya yang berupa otobiografi, yaitu Babad Raden Adipati Aria Martanagara (1923) yang dicetak dalam huruf Latin dan berbentuk prosa. Karyanya yang berisi nasihat kepada sesama manusia adalah Piwulang Batara Sunu (1918) yang disadur dari kesusastraan Jawa, yaitu Wawacan Batara Sunu. (Lubis, 2000:38-39; Lubis, 2001: 6-7, 102-111, $113,117,119$ )

Berdasarkan paparan historis di atas, terlihat relevansi dengan pengkajian WRPA dalam hal pengaruh Jawa terhadap Tatar Sunda, termasuk pengaruh kesusastraan Jawa terhadap kesusastraan Sunda. Dapat terjawablah secara umum mengapa sebuah karya sastra panji yang berbentuk wawacan dengan tokoh dan latar Jawa ini bisa hadir di tengah-tengah kesusastraan Sunda Lama. WRPA diperkirakan sebagai salah satu bukti pengaruh kesusastraan Jawa yang dikreasikan kembali oleh masyarakat Sunda lama.

\section{Unsur-Unsur Historis dalam WRPA}

Tokoh-tokoh WRPA bemama Jawa, seperti Pangeran Mangkunagara/ Sultan Yogya, Sinuhun/Sultan Mataram/Solo/Surakarta, dan Raden Keméngpati. Beberapa nama terkait dengan pelaku sejarah, seperti Sinuhun/Sultan Mataram dan Pangeran Mangkunagara. Begitu pula setting ceritanya bersifat faktual karena latar tempatnya menyebutkan nama daerah yang memang ada, seperti Yogya, Solo, Surakarta, Magelang, dan Kedu. Artinya, WRPA dapat dikatakan "berbau" sejarah. Ini alasan WRPA penting untuk dikaji, terutama dari perspektif historis.

Walaupun nama-nama tersebut dalam WRPA tidak bisa disimpulkan sebagai fakta historis, paling tidak kita dapat menemukan unsur-unsur legendaris. Sebagaimana dikemukakan Zoetmulder (1985: 534), kidung-kidung 
Panji hanya sedikit kadar historisnya, tetapi dapat dilihat sebagai unsur legendaris.

Yang lebih penting berkaitan dengan penginterpretasian dan pemahaman secara lebih tepat dan kontekstual terhadap WRPA. Djamaris (2007: 9-10) mengemukakan bahwa seringkali karya sastra yang mengandung unsur sejarah dipandang secara negatif dan menimbulkan kekecewaan banyak sejarawan karena kentalnya unsur hiburan dan banyaknya unsur dongeng dan imajinasi atau rekaan yang fantastis. Setelah meneliti Syair Perang Mengkasar dari sudut pandang ilmu sejarah, Skinner (dalam Djamaris, 2007: 10) kecewa karena banyak terkandung hal-hal yang tidak relevan dari segi sejarah dan sebaliknya hal-hal yang dipandang relevan dengan sejarah, seperti faktor ekonomi serta masalah taktik dan strategi perang sangat minim. Menurut Djamaris (2007: 11), kekecewaan dan pandangan negatif itu muncul karena karya-karya yang ada unsur sejarahnya tidak dipandang berdasarkan konvensi sastra jenis ini. Bila tidak paham akan konvensinya, karya seperti ini sering menimbulkan kekecewaan dan salah pengertian. Masalah konvensi tersebut sangat utama dan fundamental untuk memahami dan menilai karya sastra ini secara baik. Sayangnya, studi yang representatif dan komprehensif mengenai konvensi sastra sejarah masih kurang mendapat perhatian.

Mengaitkan karya sastra tradisional dengan sejarah bukan perkara yang mudah. Karena itu, perlu dibuat katagori tersendiri, yaitu sastrasejarah. Masalah semakin pelik ketika karya yang dalam kacamata modern pasti bersifat imajinatif ini diangkat sebagai bagian dari sejarah. Akan tetapi, karya sastra sejarah banyak yang bersumber dari peristiwa faktualhistoris, seperti Cerita Dipati Ukur atau yang lebih memperjelas sejarah, seperti Carita Parahyangan. Akibatnya, disebutlah ia sebagai historigrafi tradisional atau local tradition yang dapat juga dipandang sebagai sumber sejarah dari sudut metode sejarah. Tokoh-tokohnya pun dipandang sebagai tokoh legendaris (Ekadjati, 1979: 4, 6).

Dalam rangka pembatasan karya atau teks sastra-sejarah, persoalan relasi antara dunia sastra atau dunia kata-kata dengan dunia nyata tidak dapat diabaikan. Seolah-olah ada pradoksal antara sifat "sejarah" dengan konsep "sastra". Pengertian "sejarah" yang membatasi suatu teks mengacu pada realitas bahwa teks tersebut mengungkapkan realitas ekstralinguistik dari masa lampau. Sebaliknya, "sastra" menunjuk pada dunia imajinasi yang fiksional (Hermansomantri, 1979: 20-21). Masalah ini mengingatkan kita pada perdebatan klasik antara Plato dan Aristoteles mengenai hubungan antara sastra dengan kenyataan dalam kerangka kemimesisan. Teeuw (2003:181) menjelaskan bahwa mimesis ini bukan hanya berarti imitasi atau tiruan, tetapi yang lebih tepat berarti representasi atau pembayangan. Sekecil apa pun sastra pasti berkaitan dengan kenyataan. Karena itu, Hermansomantri (1979: 20-21) berpendapat bahwa pendekatan kritik sastra mimetik yang menekankan relasi teks dengan dunia nyata dan memandang seni sebagai gambaran kenyataan dalam bentuk bagaimana pun tidak mungkin tidak disinggung dalam rangka penelaahan karya sastra, terutama sastra sejarah. Pemahaman ini 
didasarkan pada hakikat sastra sebagai hasil ciptaan yang bebas, namun wajib berhubungan dengan tipe-tipe pengalaman manusia yang fundamental. Dalam konteks kelampauan, sastra berhubungan dengan sejarah, apalagi untuk karya sastra lama atau kuno.

Berdasarkan penjelasan tersebut, dalam konteksnya sebagai produk masa lampau, WRPA dipandang pasti memiliki relevansi dengan aspek historis. Inilah mengapa WRPA dilihat dari perspektif historis dalam hubungannya dengan dunia nyata, khususnya sejarah di Jawa setelah adanya Kasunanan Surakarta dan Kasultanan Yogyakarta.

Dalam hal kadar sejarah, Hermansoemantri (1979: 24) membagi karya sastra menjadi karya sastra dengan kadar sejarah yang tinggi dan karya sastra yang kadar sejarahnya rendah. WRPA termasuk golongan yang kedua. Karena itu, Ekadjati (1988: 94, 357) memasukkan teks ini ke dalam kelompok karya sastra. Akan tetapi, ini tidak menggugurkan sudut pandang yang melihat WRPA secara historis karena sekecil apa pun unsur sejarah dalam karya sastra tetap penting untuk diperhatikan. Perhatian ini akan menentukan pada pemahaman yang seutuhnya terhadap suatu karya sastra.

Jadi, perspektif historis sangat penting digunakan dalam pengkajian WRPA bukan disebabkan oleh WRPA yang termasuk karya sastra sejarah. Unsur-unsur berbau sejarah dalam WRPA memang tidak menonjol sebagaimana sastra sejarah. Padahal untuk dimasukkan sebagai sastra sejarah, unsur sejarah menjadi ciri utama atau ciri yang menonjol, seperti pada para tokoh dan latar ceritanya (lebih khususnya tempat cerita) yang dikenal di dunia nyata (Djamaris, 2007: 9). Akan tetapi, sesedikit apa pun WRPA mengandung unsur-unsur historis. Unsur-unsur faktual yang serba sedikit ini tetap menarik untuk diteliti. Kemenarikan ini disebabkan oleh kebutuhan akan pemahaman atas karya ini dalam kedudukannya yang tepat dari semua aspeknya. Kiranya pemaknaan yang tepat dan bagaimana mendudukkan WRPA sesuai dengan zamannya akan terbantu oleh penganalisisan unsur-unsur historisnya atau paling tidak unsur-unsur legendaris dalam WRPA. Karena itu, pemahaman pada unsur-unsur sejarah ini lebih tepat dan kontekstual didasarkan pada konvensi sastra sejarah.

Djamaris (2007:11-21) mengemukakan beberapa konvensi dari sastra sejarah sebagai berikut.

1. Anggapan dan kepercayaan pada umumnya masyarakat tradisional terhadap sastra sejarah sebagai karya sejarah, cerita mengenai peristiwa yang benar-benar terjadi. Bahkan, sebagian disamakan nilainya dengan kitab suci yang beritaberitanya harus diyakini secara mutlak, seperti Babad Tanah Jawi yang sudah dikaji Berg. Inilah yang oleh Kartodirdjo disebut dengan historiografi tradisional, yaitu penulisan sejarah menurut pandangan dan kepercayaan masyarakat setempat secara turuntemurun. Anggapan masyarakat tersebut disebabkan oleh beberapa sebab.

a. Judul karya ini pada umumnya memakai kata sejarah, sajarah, silsilah, babad, tambo, atau tarambo yang memang bersi- 
nonim dengan sejarah dan maknanya mengacu pada peristiwa yang faktual. Kemudian, kata-kata ini diikuti nama daerah yang memang ada secara geografis, seperti Sejarah Melayu, Sajarah Sukapura, Silsilah Kutai, Babad Demak, Serat Sarasilah Raja-Raja Jawa, danTambo Minangkabau.

b. Latar, terutama tempat-tempat yang diceritakan pada umumnya ada dalam dunia nyata juga dikenal secara geografis, seperti dalam Hikayat Banjar disebutkan tempat ceritanya di Banjarmasin, Kalimantan Selatan, juga daerah lain, seperti Majapahit di Jawa, Jambi, Palembang, dan Makasar.

c. Nama-nama tokoh cerita merupakan pelaku sejarah yang dipercayai benar-benar nyata. Sekelompok atau seorang tokoh utama diceritakan berasal dari golongan raja, bangsawan, atau pemuka masyarakat yang diyakini faktual sebagai tokoh historis.

Kiranya penyebab poin $b$ dan $c$ relevan untuk WRPA. Terdapat latar tempat cerita yang nyata ada dan dikenal secara geografis, yaitu Yogyakarta, Surakarta, Solo, Magelang, dan Kedu. Nama terakhir paling tidak sudah dikenal pada zaman Mataram Islam sebagai salah satu wilayah dalam kekuasaan Sultan Agung. Sementara itu, nama-nama pelaku cerita dapat dipandang berkaitan dengan tokoh historis atau paling tidak berhubungan dengan tokoh legendaris, seperti Pangeran
Mangkunagara, Sinuhun Mataram, dan Sultan Jogya.

2. Ciri-ciri umum penulisan sastra sejarah: percampuran rekaan dan kenyataan. Masyarakat tradisional kurang membedakan secara tegas antara unsur fantasi imajinatif dan unsur faktual. Padahal dalam keilmuan modern, terutama di bidang sastra dan sejarah, keduanya dibedakan secara tegas. Djajadiningrat (dalam Lutfi, 1997: 33) berpendapat bahwa ciri atau konvensi khas sastra sejarah seperti ini disebabkan oleh ketidakmampuan pengarang dalam membedakan rekaan dari kenyataan atau karena kuatnya kepercayaan kepada mukjizat. Pelbagai cerita rekaan digunakan sebagai pelukisan peristiwa nyata. Semua hasil sastra dianggap sebagai peristiwa sejarah dan digabungkan dengan roman sejarah, seperti cerita Panji ke dalam babad.

3. Corak penulisan sastra sejarah. Karya sastra sejarah berada dalam ketegangan antara story dan history. Maka dari itu, dalam pemahamannya timbul pertentangan antara ahli sastra yang menekankan sisi imajinasinya dan ahli sejarah yang menekankan sisi historisnya. Hal ini juga bergantung pada unsur yang ditonjolkan: apakah rekaannya, faktanya atau keduanya dianalisis secara berimbang.

4. Tujuan penulisan sastra sejarah. Tujuan ini penting karena menentukan corak dan sifat sastra sejarah atau konvensi sastra itu. Sastra sejarah yang bertujuan mengungkap fakta sejarah secara objektif yang berupa uraian peristiwa 
sejarah dalam rangkaian kronologis, untaian data, dan kejadian yang pernah ada berbeda jauh dengan sastra sejarah yang bertujuan kesastraan untuk mengagungkan raja, mengesahkan atau melegitimasi kedudukan raja, sistem adat istiadat, atau untuk menimbulkan kebanggaan masyarakat terhadap raja dan negerinya. Di samping itu, akan berbeda corak bila sastra sejarah ditulis untuk memberikan pelajaran kepada generasi pelanjut atau berfungsi didaktis. Sastra sejarah yang berorientasi pada tujuan kesusastraan akan berkonsekuensi pada fungsinya sebagai dulce et utile yang dikemukakan Horace. Artinya, selain sebagai hiburan yang menyenangkan, ia pun dapat berguna sebagai pendidikan dan nilainilai luhur sosial budaya yang disampaikan dalam bentuk nasihat.

Akhirnya Djamaris (2007: 2223) menyimpulkan bahwa pendekatan terhadap karya sastra sejarah secara umum disesuaikan dengan konvensi sastra sejarah dan secara khusus disesuaikan dengan sifat atau corak penulisan sastra sejarah. Sebagai contoh, penerapan teori sejarah terhadap sastra sejarah yang menekankan cipta sastra akan mengecewakan dan menimbulkan salah pengertian. Sebaliknya, untuk karya sastra sejarah seperti ini digunakan pendekatan sastra. Pendekatan sejarah terhadap sastra sejarah yang menekankan fakta historis akan menghasilkan kepuasaan dan pemahaman yang lebih tepat meski tidak sepenuhnya karena karya tersebut bukan semata-mata fakta sejarah, tetapi terkandung unsur rekaannya. Ia menyebutkan ada tiga macam pendekatan terhadap sastra sejarah.

1. Pendekatan sejarah yang cocok untuk sastra sejarah yang menonjolkan fakta historis.

2. Pendekatan sastra yang tepat untuk karya yang menitikberatkan pada sisi fantasi imajinatif.

3. Pendekatan terpadu, yaitu pendekatan yang menggabungkan kedua segi (sejarah dan sastra) secara proporsional dan sesuai dengan konteksnya.

Tampaknya pengkajian secara keseluruhan untuk WRPA lebih disarankan memakai pendekatan terpadu. Hal ini disebabkan pendekatan ini dapat melihat semua aspek dan mendudukkannya secara proposional sesuai dengan konteksnya. Memang WRPA hanya sedikit mengandung fakta-fakta sejarah dengan inti cerita yang fiktif. Yang berbau sejarah berkaitan dengan sebagian dari tokoh-tokohnya yang pernah ada dan latar tempatnya yang ada secara geografis, sedangkan peristiwa-peristiwa yang membangun cerita WRPA merupakan rekaan. Di sini pentingnya pendekatan sastra. Akan tetapi, pendekatan sejarah tidak berarti sama sekali disisihkan. WRPA yang sekecil apa pun mengandung nama-nama tokoh dan latar tempat yang faktual akan lebih kaya dan menyeluruh pemahaman dan pemaknaannya bila dihubungkan dengan sejarahnya. Dengan pendekatan sejarahnya, paling tidak konteks zaman yang melahirkan WRPA dan bagaimana tradisi transformasinya dapat kita perkirakan dan pahami secara lebih tepat.

Apabila paparan Ekadjati (1979: 386-387) yang sedang mengkaji Cerita 
Dipati Ukur ditarik secara umum, ada tiga cara dalam meninjau proses kelahiran suatu karya sastra sejarah secara lebih historilogi.

1. Sumber atau bahan yang digunakan untuk menyusunnya.

2. Identitas penyusunannya.

3. Situasi sosial yang melahirkan karya sastra sejarah itu.

Tiga unsur itu merupakan tritunggal yang tak mungkin dapat dipisahkanpisahkan. Ketiganya merupakan faktorfaktor dasar yang mewarnai bentuk isinya dan jalan cerita suatu karangan (sastra, sejarah, sastra sejarah). Untuk WRPA, tampaknya aspek ketiga merupakan unsur yang mungkin diungkapkan. Di sinilah pentingnya pembahasan berdasarkan perspektif historis WRPA, yaitu untuk mengungkapkan situasi sosial yang melahirkan WRPA.

Hermansoemantri (1979: 23-24) memandang aspek-aspek historis karya sastra khususnya sastra sejarah dari lima aspek, yaitu pelaku, ruang/tempat, waktu/periode sejarah, peristiwa, dan jalannya peristiwa. Kelima aspek tersebut berpadu sebagai satu kesatuan.

Ketika diterapkan pada WRPA, perspektif historis yang penting dijelaskan berkaitan dengan pelaku, yaitu tokoh-tokoh WRPA dan ruang, yaitu latar tempat cerita. Sinuhun Solo atau Surakarta dan Sultan Yogya atau Pangeran Mangkunagara termasuk nama tokoh yang ada kaitannya dengan sejarah. Karaton Solo/Surakarta, Karaton Yogya/Yogyakarta, Nageri (Kesultanan) Yogya/Yogyakarta, Nageri (Kesunanan) Surakarta/Solo, dan Magelang/Kedu menjadi latar cerita yang faktual. Di samping itu, tersebut pula nama tempat yang faktual tapi tidak menjadi setting cerita, yaitu Tegal, Pasuruhan (Pasuruan), Madiyun
(Madiun), Japara (Jepara), Pakalongan (Pekalongan), Tuban, Samarang (Semarang), Geresik (Gresik), Madura, Balangbangan (Blambangan), Rembang, Bojonagara, Kendal, Kediri, Sumenep, Surabaya, Bangkaulung, Kudus, Solo (Sala) tiga, Baliktar (Blitar), Majakarta (Mojokerto), dan Jombang. Jelas nama-nama tempat ini bersifat faktual secara geografis karena keberadaannya tidak diragukan lagi.

Mangkunagara adalah raja-raja yang memerintah Kerajaan Mangkunagaran. Kerajaan ini merupakan pecahan dari kekuasaan Susuhunan Surakarta berdasarkan Perjanjian Salatiga (1757). Raden Mas Said yang bergelar Pangeran Mangkunagara adalah raja pertama Mangkunagaran yang pernah memimpin pemberontakan pada VOC dan Raja Mataram, Susunan Paku Buwono II, yang dinilainya bersikap lemah terhadap VOC. Raja Mangkunagaran yang termasyur lainnya adalah Mangkunagara IV karena sebagai pujangga yang banyak menghasilkan karya-karya adiluhung (Ensiklopedia Nasional Indonesia 10, 1990: 137-138; Ensiklopedia Nasional Indonesia 14, 1990: 328). Menariknya, dalam WRPA Pangeran Mangkunagara merupakan tokoh cerita yang berkedudukan sebagai Sultan Yogya. Penokohan ini menandakan bahwa pengarang WRPA tidak memahami sejarah raja-raja di Solo/Surakarta, Yogyakarta, dan Mangkunagaran. Ini memperkuat dugaan bahwa penulis WRPA adalah orang Sunda sendiri. Sepertinya kurang masuk akal pengarang Jawa yang menulis nama raja Jawa secara kacaubalau karena memiliki penghormatan yang tinggi terhadap kedudukan para raja Jawa. 
Kesunanan Surakarta merupakan pecahan dari Kerajaan Mataram. Kerajaan ini terbentuk sebagai akibat Perjanjian Giyanti (13 Februari 1755). Sebelum perjanjian ini, Surakarta merupakan pusat pemerintahan Kerajaan Mataram. Paku Buwono II dapat dikatakan sebagai raja terakhir Kerajaan Mataram, sedangkan raja pertama dari Kesunanan Surakarta adalah Paku Buwono III. Pada masa revolusi, raja Surakarta tidak banyak terlibat dalam gerakan kemerdekaan RI. Karena itu, kekuasaan politik raja ini dihapus dan wilayah kerajaan Surakarta secara administratif dimasukkan ke dalam Propinsi Jawa Tengah (Ensiklopedia Nasional Indonesia 15, 1991: 427).

Kesultanan Yogyakarta Hadiningrat pun merupakan pecahan Kerajaan Mataram dan terbentuk sebagai akibat Pejjanjian Giyanti. Mulanya di saat Paku Buwono II menjelang wafat, Pangeran Mangkubhumi menobatkan diri sebagai raja Ia mendirikan istana di Desa Bering, dekat Kota Gede, Yogyakarta. Setelah perjanjian Giyanti, Pangeran Mangkubhumi menjadi raja dengan gelar Sultan Hamengku Buwono I. Semua raja Yogyakarta menggunakan gelar ini. Istana yang baru didirikan berada di tempat yang sekarang. Di antara keluarga kerajaan, ada yang kemudian terkenal, yaitu Pangeran Dipenogoro. Ia adalah cucu Sultan Hamengku Buwono I. Ada pun Sultan yang paling berjasa kepada Republik Indonesia adalah Sultan Hamengku Buwono IX (Ensiklopedia Nasional Indonesia 17, 1991: 393).

Keraton Surakarta itu tempat kediaman keluarga raja Surakarta Hadiningrat, sekaligus menjadi ibu kota dan pusat pemerintahan kerajaan ini.
Asal mula tempat keraton Surakarta ini adalah sebuah desa bernama Solo. Keraton ini mulai dipakai pada tahun 1744. Istana raja ini menggantikan keraton Kartasura yang telah hancur pada tahun 1742 akibat pemberontakan masyarakat Cina yang bersekutu dengan Raden Mas Garendi (Ensiklopedia Nasional Indonesia 15, 1991: 427).

Keraton Yogyakarta sebagai istana bagi Dinasti Sultan Hamengku Buwono berada di Daerah Istimewa Yogyakarta. Luasnya kurang lebih $14.000 \mathrm{~m}^{2}$. Keraton ini menjadi poros "garis imajiner" utara selatan yang dihormati masyarakatnya sampai sekarang. Garis itu dari utara ke selatan melewati Gunung Merapi, Monumen Yogya Kembali, Tugu Pal Putih, Keraton Yogyakarta, Panggung Pondok Pesantren Krapyak, dan Samudra Hindia. Keraton Yogyakarta berdiri tanggal 7 Oktober 1756 yang diperingati sebagai hari jadi Kota Yogyakarta (Ensiklopedia Nasional Indonesia 17, 1991: 391).

Semua unsur cerita yang dijelaskan di atas dapat dipandang historis-faktual dari segi penamaan saja. Hal ini disebabkan aspek-aspek waktu, peristiwa, dan proses peristiwa berupa rekaan yang imajinatif. Dengan demikian, nama-nama tokoh dan latar tempat dalam WRPA bersifat legendaris.

Untuk menjawab pertanyaan mengapa cerita Panji yang masuk ke Tatar Sunda itu bertokoh dan bersetting Jawa pada zaman sesudah Mataram Islam? Memang tidak mudah menjawab pertanyaan ini. Akan tetapi, sebagai jawaban sementara dapat dikaitkan dengan masa superioritas 
kebudayaan Jawa terhadap masyarakat Sunda. Dari jejak historis, kita ketahui bahwa hegomininya terjadi di zaman Mataram Islam dan sesudahnya. Zaman ini merupakan masa puncak transformasi kebudayaan Jawa terhadap Sunda. Proses penyebaran kultural ini kiranya masih terus berlangsung sampai zaman Kesultanan Mataram Islam terpecah dua: Kasunanan Surakarta dan Kesultanan Yogyakarta. Oleh karena itu, termasuklah bukti pengaruh itu kita dapatkan melalui WRPA. Artinya, melalui WRPA kita pun mendapatkan bukti bahwa pengaruh Jawa itu masih bertahan meskipun Tanah Sunda sudah tidak dijajah Mataram Islam di sekitar abad XVIII dan IX. Mungkin jawaban ini kurang memuaskan, tetapi paling tidak didapatkan gambaran ke arah itu.

\section{PENUTUP}

Dari paparan di atas, tergambarlah WRPA dalam perspektif historis. Perspektif pertama dilihat dalam jejak historis yang relevan secara umum, terutama dalam hubungan kebudayaan Jawa dengan Sunda. Perspektif historis berikutnya dilihat secara internal, yaitu mengungkap unsur-unsur historis yang ada di dalam WRPA yang lebih tepat dipandang dari segi sastra sejarah. Penemuan internalnya dinilai bersifat legendaris dalam dua unsur historis, yaitu pelaku dan tempat. Tokoh-tokoh cerita dalam WRPA yang bersifat legendaris adalah Sinuhun/Sultan Mataram dan Pangeran Mangkunagara. Begitu pula setting ceritanya bersifat faktual karena latar tempatnya menyebutkan nama daerah yang memang ada, seperti Yogya, Solo, Surakarta, Magelang, dan Kedu. Jadi,
WRPA dapat dikatakan "berbau" sejarah.

Dapat diperkirakan naskahnaskah WRPA muncul setelah zaman Mataram Islam terpecah menjadi dua kerajaan pada kisaran abad ke-18 atau sesudahnya ketika masih terjadi transformasi kebudayaan Jawa terhadap kebudayaan Sunda. Oleh karena itu, dalam pengkajiannya yang lebih mendalam, WRPA disarankan dipahami dalam konteks sosial budaya dan konvensi bahasa dan sastra pada kisaran zaman tersebut.

\section{DAFTAR PUSTAKA}

Baried, Siti Baroroh et al. 1994.

Pengantar Teori Filologi. Yogyakarta:

Badan Penelitian dan Publikasi Fakultas. Seksi Filologi Fakultas SastraUGM.

Ekadjati, Edi S. 1979.

Cerita Dipati Ukur Sebuah Karya Sastra Sejarah Sunda. Disertasi. Jakarta: Universitas Indonesia.

1988.

Naskah Sunda Inventarisasi dan

Pencatatan. Bandung. Lembaga Penelitian Universitas Padjadjaran dan The ToyotaFoundation.

et al. 1994.

Empat Sastrawan Sunda Lama. Jakarta: Depdikbud. Dirjen Kebudayaan. Direktorat Sejarah dan Nilai Tradisional. Proyek Pengkajian dan Pembinaan NilaiNilai Budaya.

1995.

Kebudayaan Sunda (Suatu Pendekatan Sejarah). Jakarta: Pustaka Jaya.

\& Darsa, Undang A. 1999. 
Katalog Induk Naskah-Naskah Nusantara. Jilid 5A Jawa Barat Koleksi Lima Lembaga. Jakarta: Yayasan Obor Indonesia.

de Graaf, H.J. \& Pigeaud, Th. 2003. Kerajaan Islam Pertama di Jawa; Sejarah Politik Abab XV dan XVI. Jakarta: Pustaka Utama Grafiti.

2007.

Sastra Indonesia Lama Berisi Sejarah. Jakarta: Pusat Bahasa.

Hamid, Ismail. 1987.

Perkembangan Kesusastraan Melayu Lama. Selangor:Longman.

Hardjasaputra, A. Sobana dan Nina Herlina Lubis. 1999.

Pedoman Penulisan dan Evaluasi Skripsi. Jatinangor: Program Studi Ilmu Sejarah Fakultas Sastra Universitas Padjadjaran.

Hardjasaputra, A. Sobana. 2004.

Penelitian dan Penulisan Sejarah: Materi Kuliah. Jatinangor. Jurusan Ilmu Sejarah Fakultas SastraUnpad.

2004.

Bupati di Priangan. Bandung: Pusat Studi Sunda.

Hermansoemantri, E. 1979.

Sajarah Sukapura Sebuah Telaah Filologis (Disertasi). Jakarta: Universitas Indonesia.

Heryana, Agus et al. 1998.

Wawacan Panji Kerenengpati. Bandung: Departemen Pendidikan dan Kebudayaan. Direktorat Jenderal Kebudayaan.

Liaw, Yock Fang. 1991.
Sejarah Kesusastraan Melayu Klasik. Jakarta: Erlangga.

Lubis, Nina Herlina. 2000.

Tradisi dan Tranformasi Sejarah Sunda. Bandung: Humaniora Utama Press.

2001.

Konflik Elite Birokrasi Biografi Politik Bupati R.A.A. Martanagara. Bandung: Humaniora Utama Press. 2003.

Banten dalam Pergumulan Sejarah; Sultan, Ulama, Jawara. Jakarta: Pustaka LP3ES Indonesia

et al. 2003.

Sejarah Tatar Sunda. Jilid 1. Bandung: Satya Historica.

Lutfi, Muhammad. 1997.

"Hubungan Sejarah dan Filologi; Pandangan Hoesein Djajadiningrat", dalam Tradisi Tulis Nusantara. Jakarta: Masyarakat Pernaskahan Nusantara.

Margana, S. 2004.

Kraton Surakarta dan Yogyakarta 17691874. Yogyakarta: Pustaka Pelajar.

Moriyama, Mikihiro. 2005. Semangat Baru Kolonialisme, Budaya Cetak, dan Kesastraan Sunda Abad ke-19. Terjemahan Suryadi. Jakarta: KPG (Kepustakaan Populer Gramedia).

Poerbatjaraka, R. Ng. 1968. Tjeritera Pandji dalam Perbandingan. Jakarta: Gunung Agung.

Pradotokusumo, Partini Sardjono. 1986. 
Kakawin Gajah Mada. Bandung: Binacipta.

2005.

Pengkajian Sastra. Jakarta: Gramedia Pustaka Utama.

Reynolds, L.D.. dan Wilson, N.G. 1978. Scribes dan Scholars. Oxford: Clarendon Press-Oxford.

Rickefs, M.C. 2005.

Sejarah Indonesia Modern 12002004. Jakarta: Serambi Ilmu Semesta.

Robson, S.O. 1994.

Prinsip-Prinsip Filologi Indonesia. Jakarta: RUL.

Rosidi, Ajip. 2004.

"Perkembangan Bahasa dan Sastera Daerah", dalam Sundalana, no. 3: 143-153. Bandung: Pusat Studi Sunda.

Sastrahadiprawira, R. Memed \& Wirasutisna, Haksan. 1980. Carita Mantri Jero. Jilid 1-2. Jakarta: Depdikbud.
Sedyawati, Edi. 2007.

Budaya Indonesia; Kajian Arkeologi, Seni, dan Sejarah. Jakarta: Raja Grafindo Persada.

Saefuddin, Erlan. 2009.

Wawacan Raden Panji Atmaka; Satu Kajian Filologis Cerita Panji Sunda. Bandung: Program Pasca Sarjana Universitas Padjadjaran.

Sukanda, Viviane et al. 1990.

Katalog Rayisonné Naskah Jawa Barat I Naskah Islam. Jakarta: E.F.E.O dan Puslit-Arkenas.

Teeuw, A. 1982.

Khazanah Sastra Indonesia. Jakarta: Balai Pustaka.

2003.

Sastera dan Ilmu Sastera. Jakarta: Pustaka Jaya.

Zoetmulder, P.J. 1983.

Kalangwan, Sastra Jawa Kuno Selayang Pandang. Jakarta: Djambatan. 